\title{
A sporadic case of myositis ossificans of the forearm presenting clinically as mesenchimal tumor
}

\author{
Rijedak slučaj osificirajućeg miozitisa podlaktice s kliničkom \\ prezentacijom mezenhimalnog tumora
}

\author{
Damir Grebić ${ }^{1 *}$, Iva Pozderac², Ivan Milas³, Domagoj Eljuga ${ }^{3}$
}

\begin{abstract}
Aim: Myositis ossificans is a benign, solitary, self-limiting lesion characterized by extraskeletal formation of focal heterotopic bone and cartilage in soft-tissue. It generally affects the muscles, ligaments, and fascia. Myositis ossificans usually occurs in young adults mostly after localized trauma, with predilection in the anterior muscle groups of the thighs and arms. The aim of this case report was to present a rare case of myositis ossificans in the forearm, which presented as a bump on the forearm and weakness of the hand. The clinical signs and imaging appearance can be easily confused with malignant lesions, as was the case in our patient. Case report: A 48-year old woman was presented with a palpable formation in the distal and volar part of the right forearm. She had suffered from weakness of the forearm for a while, and had no history of acute injury or trauma of the forearm. Preoperative magnetic resonance imaging demonstrated malignant fibrous histiocytoma-like tumor, but final pathohistological examination revealed rare disease, myositis ossificans. Postoperatively, the patient had some minor neurological deficits, such as paresthesia, and less flexible fingers. After six months, the patient showed a major improvement in physical therapy, and the MRI findings were unremarkable. Conclusion: Myositis ossificans should be considered as a possible diagnosis for a soft-tissue mass in the forearm shown on the imaging findings. Due to the rare location of the lesion, the postoperative histopathological examination is necessary for making an ultimate diagnosis.
\end{abstract}

Key words: forearm; magnetic resonance imaging; mesenchymal tumor; myositis ossificans

\author{
${ }^{1}$ Department of General and Oncological \\ Surgery, Clinical Hospital Center Rijeka, \\ School of Medicine, University of Rijeka, \\ Rijeka, Croatia \\ ${ }^{2}$ Student of General Medicine, School \\ of Medicine, University of Rijeka, Rijeka, \\ Croatia \\ ${ }^{3}$ Department of Oncoplastic Surgery, \\ Clinic for Tumours Clinical Hospital Center \\ 'Sestre Milosrdnice' Zagreb, School of \\ Medicine, University of Zagreb, Zagreb, \\ Croatia
}

Sažetak. Cilj: Osificirajući miozitis je benigna, solitarna, samoograničavajuća lezija koja je karakterizirana ekstraskeletnim tvorbama fokalne heterotopične kosti i hrskavice u mekim tkivima. Uglavnom zahvaća mišiće, ligamente i fascije. Osificirajući miozitis pretežno se javlja u mlađih osoba nakon lokalizirane traume u području prednje skupine mišića natkoljenica i ruku. Cilj ovog prikaza slučaja je opisati rijedak slučaj osificirajućeg miozitisa podlaktice koji se prezentirao izbočinom u području podlaktice te slabošću ruke. Klinički znakovi i slikovni prikazi često se mogu poistovjetiti s malignim lezijama, kao što je bio slučaj i kod naše pacijentice. Prikaz slučaja: 48-godišnja žena dolazi zbog tvorbe u distalnom i volarnom dijelu desne podlaktice. $U$ anamnezi navodi da je nekoliko tjedana osjećala slabost podlaktice, ali bez ikakve prethodne akutne ozljede ili traume podlaktice. Preoperativna snimka magnetske rezonancije pokazala je tvorbu nalik malignom fibroznom histiocitomu. Završna dijagnoza postavljena patohistološkim pregledom preparata govorila je u prilog rijetkoj bolesti, osificirajućem miozitisu. Nakon operacije pacijentica je imala parestezije te manje razgibane prste. Nakon šest mjeseci pacijentica je pokazala značajno poboljšanje na fizikalnoj terapiji te su nalazi magnetske rezonancije bili bez osobitosti. Zaključak: Osificirajući miozitis valja uzeti u obzir kao moguću dijagnozu za mekotkivne tvorbe u području podlaktice dokazane slikovnim metodama. S obzirom na rijetku lokaciju lezije, postoperativna patohistološka analiza nužna je za dobivanje točne dijagnoze.

Ključne riječi: magnetska rezonancija; mezenhimalni tumor; osificirajući miozitis; podlaktica

\author{
*Corresponding author: \\ Damir Grebić, MD, PhD. \\ Department of General and Oncological \\ Surgery, Clinical Hospital Center Rijeka, \\ School of Medicine, University of Rijeka \\ Krešimirova 42, 51000 Rijeka \\ e-mail: damir.grebic@medri.uniri.hr
}




\section{INTRODUCTION}

Myositis ossificans is a rare, benign, non-neoplastic ossifying lesion with a self-limiting clinical course. This condition is characterized by focal formation of heterotopic bone and cartilage in extraskeletal soft-tissue ${ }^{1-3}$. Most commonly affected areas are the flexor muscles of the arm and the extensor muscles of the thigh ${ }^{4-6}$. Myositis ossificans has a prevalence of less than 1 per 1 million, and it usually occurs in active adoles-

This case report has shown the patient with the palpable lump in the forearm. Magnetic resonance was suspicious for mesenchimal tumor, like malignant fibrous histiocytoma, but finally pathohistological examination revealed myositis ossificans.

cents and young adults with a slight male predominance ${ }^{7-9}$.

The etiology of myositis ossificans is variable, around 60 to $75 \%$ of cases occur as a result of a muscle injury such as repetitive minor mechanical trauma. In $25 \%$ of cases, ischemia, inflammation, infections, burns, neuromuscular disorders, hemophilia or drug abuse have been implicated as a possible causative factor ${ }^{1-3}$. There is also an extremely rare, genetically determined disease with a severe course: myositis ossificans progressiva, also known as Munchmeyer's disease ${ }^{10}$.

Clinical presentation is generally characterized by an ossifying soft-tissue mass ${ }^{1,11}$. Early in the disease, the lesion is soft and painful, and within a few weeks, a firm and often painful mass develops in the affected muscles. This lesion matures over 6-12 months, and eventually ossifies and becomes painless ${ }^{1,12}$.

Myositis ossificans can easily be confused with malignant lesions, such as osteosarcoma and soft-tissue sarcoma ${ }^{12}$. Due to this, the appropriate imaging and histopathological examination are crucial for confirmation an accurate diagnosis. Magnetic resonance imaging (MRI) is the preferred diagnostic tool in the evaluation of a soft-tissue mass ${ }^{1,12}$ although the final diagnosis is always pathohistological. We present a rare case of the woman in the middle age with diagnosis of myositis ossificans occuring in the right forearm that presenting clinically as mesenchimal tumor mass suspicious for malignant fibrous histiocytoma tumor.

\section{CASE REPORT}

A 48-year old woman was referred to our hospital because of a formation in her right forearm. Her medical history found out that she had been suffering from weakness of finger motion for a few weeks and that she had had no history of a specific acute injury, or massage or exercise-related trauma of the forearm. On physical examination a single, large, oval mass was palpable. It was a slightly tender, hard, not well-circumscribed, poorly mobile, painless lump on the volar side of the right distal forearm. The laboratory findings, including white bood cell count, erythrocyte sedimentation rate and C-reactive protein level were normal. A MRI scan revealed a poorly defined, serpiginous, spindle-like and expansive mass within the flexor superfitial muscles of the forearm. The mass in the superficial flexor compartment was measuring $100 \times 32 \times 22$ milimeters in diameter and was showing heterogeneous signal intensity. On T2-weighted images, the signal intensity of the lesion was intermediate to high. Whereas on T1-weighted images, the lesion

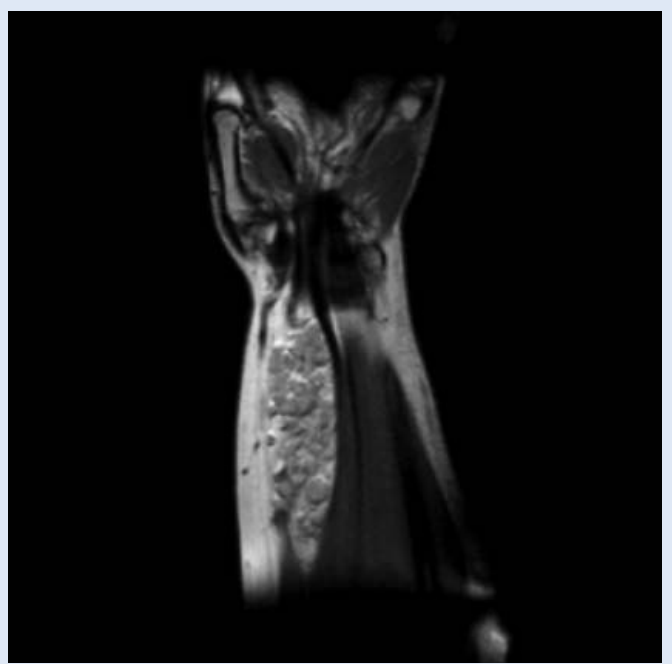

Figure 1 Magnetic resonance imaging of the distal part of the right forearm. Coronal section. MRI scan revealed a poorly defined, serpiginous, spindle-like and expansive mass within the muscle fibers of flexor digitorum superficialis muscle suspicious for mesenchimal tumor. 


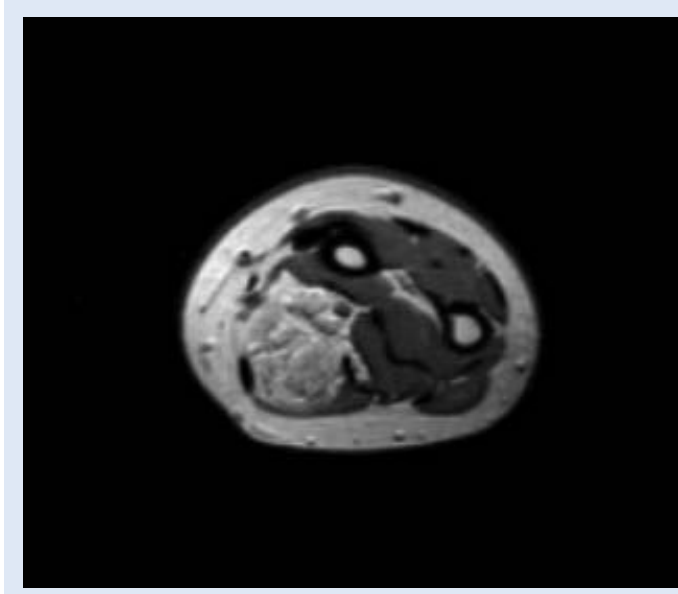

Figure $2 \mathrm{MRI}$ of the distal right forearm. Transverse section. You can see the expansive tumor mass between the muscle fibers of the flexor digitorum superficialis muscle.

exhibited intermediate to low signal intensity similar to the adjacent muscles. After the injection of a contrast agent, there was no difference in signal intensity. The surrounding fascia and muscles were not affected and there were no sings for tissue infiltration. Due to this, MRI findings were suspicious for mesenchimal tumor like malignant tumor fibrous histiocytoma as it is often well incapsulated without sings for tissue infiltration (Figures 1, 2).

The patient underwent a surgical procedure during which the tumor process was extirpated completely from the superfitial flexor muscle (Figure 3). During surgical extirpation the tumor process was also suspected for mesenchimal tumor and was well incapsulated with mass effect on median nerve, but without its infiltration (Figure 4). The specimen was sent to histopathological examination, which showed a capsulated irregular mass measuring $100 \times 30 \times 20$ milimeters in size, firm consistency, bony tissue showing hemorrhagic and necrotic areas. It also revealed bone and osteoid formations with many osteoblasts and fibrous tissue with rich vascularization in the periphery of the mass, which was located near the muscle. In detail the histopathological examination showed a typical zonal pattern with three zones: the central zone of proliferating fibroblasts with areas of hemorrhage and necrotic muscles, the intermediate zone characterized by osteoblasts with immature osteoid formation

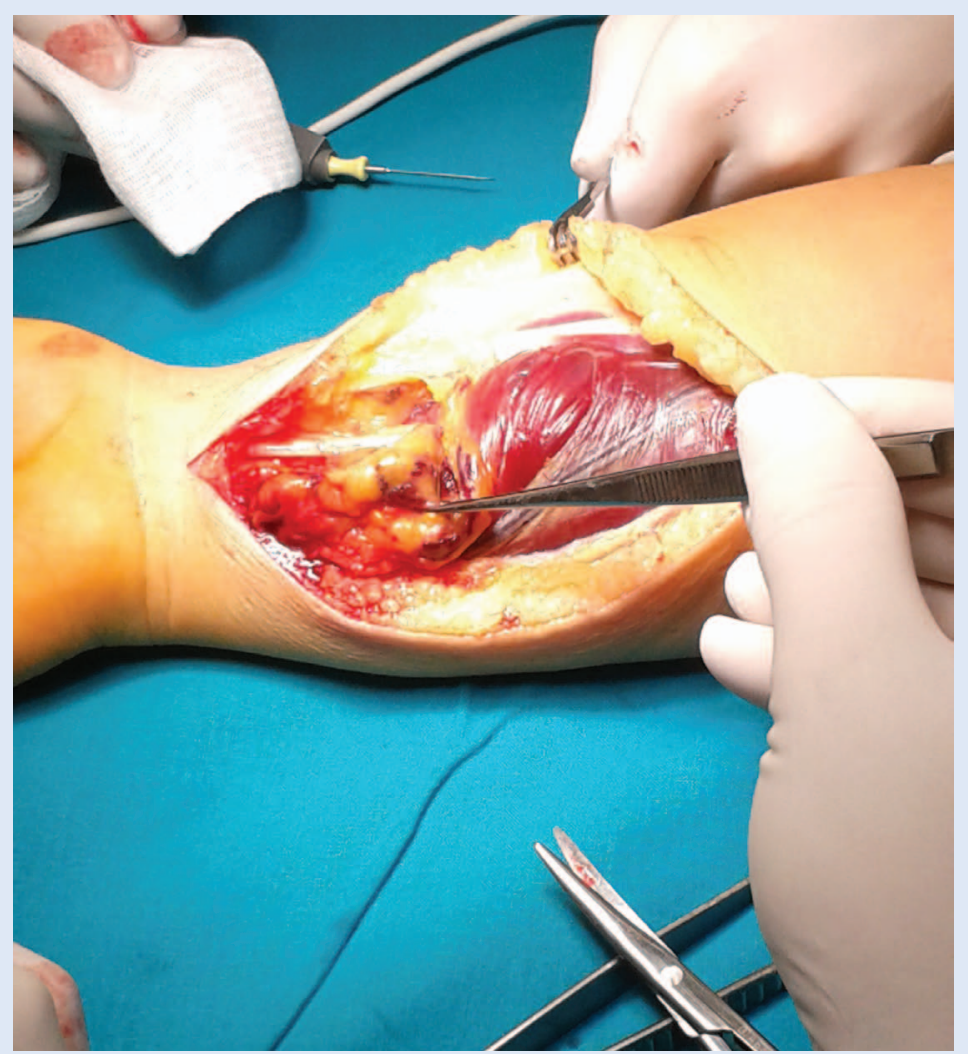

Figure 3 Tumor preparation. Forceps are pointing to the tumor mass.

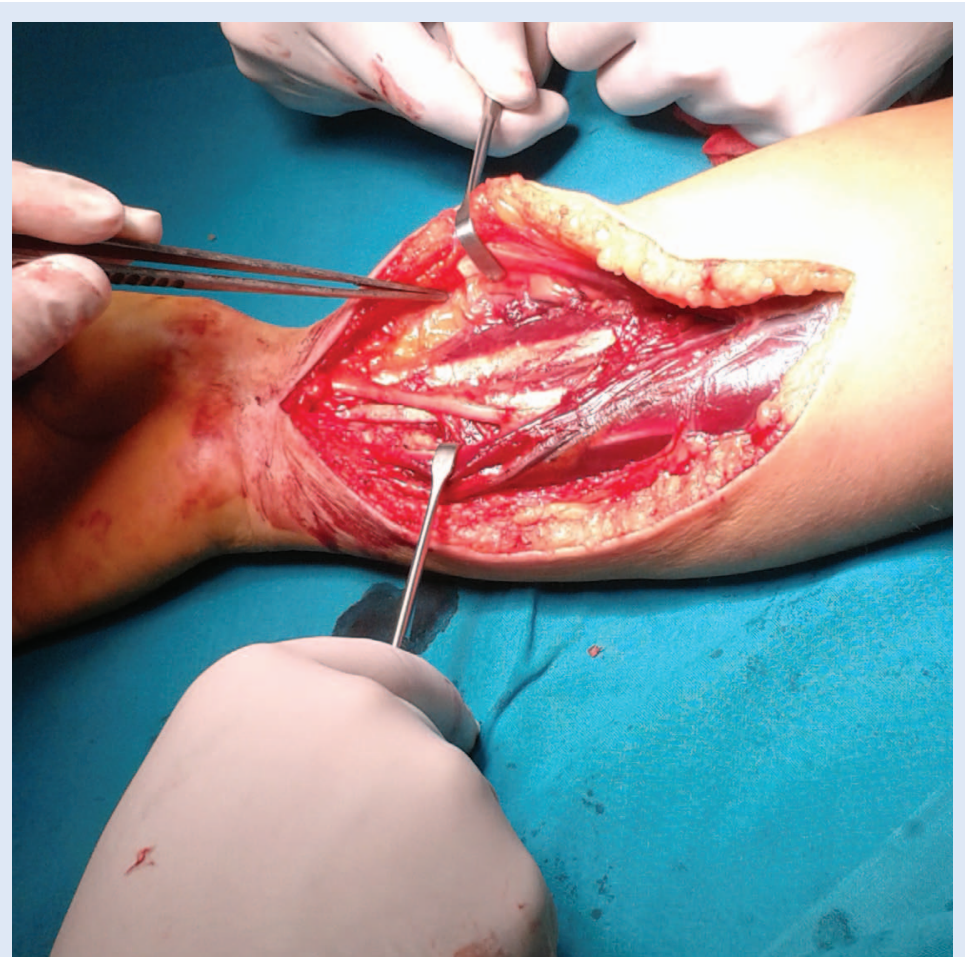

Figure 4 Anatomical structures after extirpation of tumor mass. Muscle fibers of the flexor digitorum superficialis muscle are separated by the retractors in the area where the tumor was located. Median nerve is visualised proximal from the carpal tunnel. Tumor was close to median nerve, but did not infiltrate it. 
and the peripheral zone composed of mature bone separated from the surrounding tissue by fibrous and muscle tissue. No malignant signs were observed in the sample and the edges of the sample were tumor-free. Finally, on the basis of the histopathological findings, a diagnosis of myositis ossificans was made.

The postoperative period passed without complications. Three days following the surgical excision, the drain was removed. The patient was discharged on the third day after the surgery in

Although magnetic resonance is crucial for diagnosis, finally diagnosis is always established by pathohistological examination of the specimen. We emphasised that in case of well incapsulated lesions, this rare disease, myositis ossificans should not been forgotten.

good overall condition with the recommendation to begin physical therapy. The sutures were extracted on the tenth day after the operation. The wound healed primarily without complications. At the 1-month follow-up control the patient had some minor neurological deficits (paresthesia) around the scar and slightly less flexible fingers. After 6 months, the patient showed a significant improvement in physical therapy. Restricted finger movements and neurological deficits com-

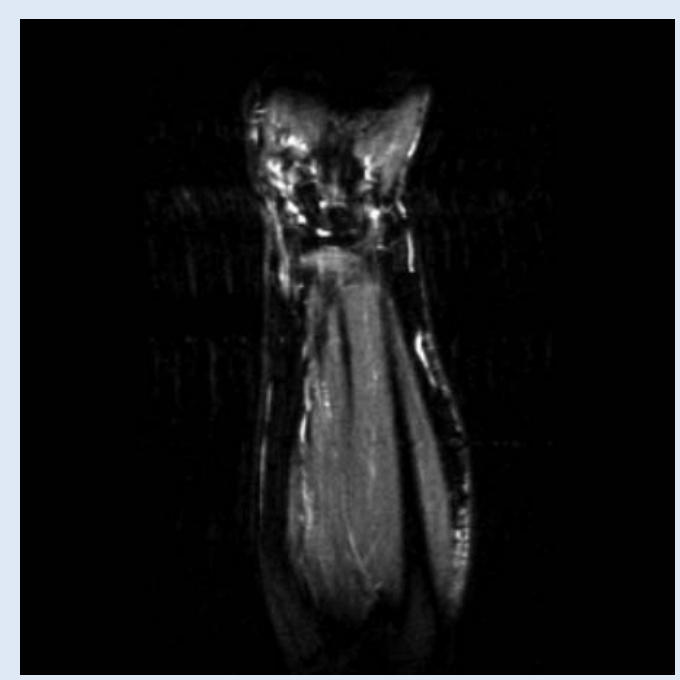

Figure $\mathbf{5}$ Control magnetic resonance of the distal right forearm performed one year after the operation. Magnetic resonance revealed no suspicious masses in the forearm. The surrounding fascia and muscles were not affected. pletely disappeared. The MRI was performed 1 year after the operation and revealed no suspicious masses in the forearm (Figure 5). At the 1-year follow-up examination the patient was asymptomatic and exhibited normal function and a full range of motion.

\section{DISCUSSION}

Myositis ossificans, first described by Theodore von Dusch in 1868. is a rare benign, non-neoplastic, localized, ossifying lesion. It usually follows trauma, although our patient had no history of any specific injury, massage or exercise-related trauma. It can be seen at any age, most commonly in adolescents and young males, but rarely occurs in middle-aged patients ${ }^{5,12}$ as it was diagnosed in our patient. To our knowledge, the youngest documented patient was a five-monthold girl ${ }^{13}$ and the oldest an 83-year-old woman ${ }^{14}$. Generally, the most affected areas in the upper extremity are the flexor muscles, particulary the brachial muscle, as well as the quadriceps, hamstrings, and gluteus muscles in the lower extremity $^{4,6,12}$. However, involvement of the forearm is very rare and only few cases have been reported so far. Say et al. reported a rare case of myositis ossificans on the forearm in a 10 -year-old girl ${ }^{11}$. Pathogenesis is well defined for traumatic myositis ossificans, but it still remains unclear for nontraumatic myositis ossificans ${ }^{1,14}$. In 60 to 75 percent of cases with an apparent history of traumatic injury, it can be assumed that the process begins with tissue necrosis or hemorrhage followed by rich reparative fibroblastic and vascular proliferation with eventual ossification ${ }^{1,14}$.In approximately 25 percent of cases, there is no apparent history of preceding trauma, and pathogenesis may include ischemia, inflammation, infections, burns, neuromuscular disorders (paraplegia, poliomyelitis, tabes dorsalis, syringomyelia), hemophilia (factor IX deficiency), tetanus, post-intramuscular injection, drug abuse $\mathrm{e}^{1,14}$ or high calcium and protein content diet of those consuming red meat ${ }^{12}$. In our case the etiology factors were still unknown. There are four conditions that are crucial in the pathogenesis of myositis ossificans: the initiating event; sending the signal from the site of injury; the presence of 
mesenchymal cells which may differentiate into osteoblasts and the environment favourable to the formation of a heterotopic bone ${ }^{1,8}$. The histologic course of myositis ossificans progresses from an immature highly cellular fibroblastic lesion to a mature mass with peripheral lamellar bone ${ }^{1,12,14}$. With maturation of the lesion, a typical zonal pattern develops with three distinct zones: the centre zone consisting of rapidly proliferating stromal fibroblasts with areas of haemorrhage and necrotic muscles; the intermediate zone characterized by osteoblasts with immature osteoid formation; and the peripheral zone composed of mature lamellar bone separated from the surrounding tissue by fibrous and muscle tissue ${ }^{1,3,4,6,9,12}$. All of these pathohistological characteristics that are typical for myositis ossificans had also our patient in pathohistological examination of the specimen.

Clinical presentation of myositis ossificans is generally characterized by an ossifying soft-tissue mass. It can present incidentally, as in our patient, or acutely with pain, limitation of joint movement, or complications arising from nerve compression $^{1,6}$. Early in the disease, the affected area is soft, swollen and painful. Within six weeks, a firm and often painful mass develops in the affected muscles. This lesion matures over 6-12 months, and eventually ossifies and becomes hard, painless and well-circumscribed ${ }^{1,2,6,7,12,14}$. As a result, patients report muscle pain that persists longer than would be expected for a simple muscle strain or contusion. Pain is commonly a result of the lesion causing mechanical irritation of the bursa, tendon, or joint. When myositis ossificans compresses nearby neurovascular structues, associated paresthesia, weakness, lymphedema and venous thromboembolic disease have been reported $^{1,6,12}$ as was seen in our patient like paresthesia symptoms due to tumor mass effect on median nerve.

$\mathrm{MRI}$ is the preferred single modality for imaging soft-tissue masses ${ }^{1,12}$ and therefore it was also used in our case. For early stage lesions, T2weighted images show a heterogeneous localized mass with high signal intensity in the central area. As the lesion matures, the peripheral ossification becomes denser and the T2-weighted images show a hyperintense area with a surrouning hypointense rim. On T1-weighted images, the lesion is isointense to the muscle $e^{1,2,4-9,12,15,16}$. In our case, MRI showed heterogeneous signal intensity of the lesion within the muscles of the flexor compartment (flexor superfitial muscle) in the distal and volar part of the right forearm. The MRI findings were suggestive for mesenchimal tumor. On T2-weighted images, the signal intensity of the lesion was intermediate to high, whereas on T1-weighted images, the lesion exhibited intermediate to low signal intensity similar to the adjacent muscles. These signs were not pathognomonic, but may suggest the mesenchimal tumor like malignant fibrous histiocytoma as it has similar MRI assessment.

The postoperative period of our patient passed without complications. The follow-up examination and MRI were conducted and revealed no suspicious masses in the forearm one year after the operation. The patient showed a significant improvement in physical therapy and exhibited normal function and a full range of motion. Since myositis ossificans is a benign, self-limiting process, its prognosis is excellent. There is no need for further therapy once the diagnosis of myositis ossificans has been established by excision ${ }^{1,6}$.

\section{CONCLUSION}

In conclusion, making a diagnosis of myositis ossificans in cases when this condition is not associated with trauma is challenging, because it may mimic benign or malignant tumors, but in such cases myositis ossificans should be always considered as a possible diagnosis. In spite of MRI as the method of choice for analysing the soft tissue, final diagnosis must be confirmed by pathohistological examination of the specimen after its complete surgical extirpation.

Conflicts of interest statement: The authors report no conflicts of interest.

\section{REFERENCES}

1. Walczak BE, Johnson CN, Howe BM. Myositis ossificans. J Am Acad Orthop Surg 2015;23:612-22.

2. Yamaga K, Kobayashi E, Kubota D, Setsu N, Tanaka Y, Minami $Y$ et al. Pediatric myositis ossificans mimicking osteosarcoma. Pediatr Int 2015;57:996-9.

3. Luczynska E, Kasperkiewicz H, Domalik A, Cwierz A, Bobek Billewicz B. Myositis ossificans mimicking sarcoma, 
the importance of diagnostic imaging. Pol J Radiol 2014;79:228-32.

4. Al-Timimy QAH, Al-Edani MS. Myositis ossificans: A rare location in the foot. Report of a case and review of literature. Int J Surg Case Rep 2016;26:84-7.

5. Li PF, Lin ZL, Pang ZH. Non-traumatic myositis ossificans circumscripta at elbow joint in a 9-year old child. Chin Journal Traumatol 2016;19:122-4.

6. Akahane T, Mori N, Nakatsuchi Y. Myositis ossificans occupying the thenar region: a case report. J Med Case Rep 2015;9:105-9.

7. Oc Y, Ozcan MS, Sezer HB, Kilinc BE, Eren OT. Nontraumatic myositis ossificans of hip: A case presentation. Case Rep Orthop 2016; Forthcoming.

8. Luczynska E, Kasperkiewicz H, Domalik A, Cwierz A, Bobek Billewicz B. Myositis ossificans of the quadriceps femoris mimicking sarcoma as a diagnostic and therapeutic problem. Pol J Radiol 2013;85:520-6.

9. Aneiros-Fernandez J, Caba-Molina M, Arias-Santiago $S$, O’Valle F, Hernandez-Cortes P, Aneiros-Cachaza J. Myositis ossificans circumscripta without history of trauma. J Clin Med Res 2010;2:142-4.
10. Sheth SB, Santhosh Kumar SN, Sabhlok S, Singh M. Munchmeyer's disease - a rare case report and review of literature. Dentomaxillofac Radiol 2014;43:20140022.

11. Say F, Coskun S, Buelbuel M, Alici O. Pediatric myositis ossificans on the forearm in a 10-year-old girl. J Pediat Orthop 2015;24:223-5.

12. Mahale YJ, Vyawahare CS, Dravid NV, Upase A, Rathi R. A rare case of non traumatic myositis ossificans circumscripta. J Orthop Case Rep 2015;5:15-7.

13. Heifetz SA, Galliani CA, DeRosa GP. Myositis (fasciitis) ossificans in an infant. Pediatr Pathol 1992;12:223-9.

14. Nishio J, Nabeshima K, Iwasaki H, Naito M. Non-traumatic myositis ossificans mimicking a malignant neoplasm in an 83-year-old woman. J Med Case Rep 2010; 4:270.

15. Lacout A, Jarraya M, Marcy PY, Thariat J, Carlier RY. Myositis ossificans imaging: keys to successful diagnosis. Indian J Radiol Imaging 2012;22:35-9.

16. Luczynska E, Kasperkiewicz H, Domalik A, Cwierz A, Bobek Billewicz B. Myositis ossificans mimicking sarcoma, the importance of diagnostic imaging - case report. Pol J Radiol 2014;79:228-32. 